\title{
The Active Ageing Index and policy making in Italy
}

\author{
Andrea Principi ${ }^{1}$ (D), Mirko Di Rosa ${ }^{2}$, Antia Domínguez-Rodríguez ${ }^{3}$, Maria Varlamova ${ }^{4}$, \\ Francesco Barbabella ${ }^{1 *}$ (D), Giovanni Lamura ${ }^{1}$ and Marco Socci ${ }^{1}$ (iD) \\ ${ }^{1}$ Centre for Socio-Economic Research on Ageing, National Institute of Health and Science on Ageing \\ (IRCCS INRCA), Ancona, Italy, ${ }^{2}$ Unit of Geriatric Pharmacoepidemiology and Biostatistics (IRCCS \\ INRCA), Ancona, Italy, ${ }^{3}$ Social Determinants of Health and Demographic Change (UPV/EHU) and \\ Facultad de Sociologia, University of A Coruña (UDC), A Coruña, Spain and ${ }^{4}$ MSCA ITN EuroAgeism, \\ Jagiellonian University, Cracow, Poland \\ ${ }^{*}$ Corresponding author. Email: f.barbabella@inrca.it
}

(Accepted 12 November 2021)

\begin{abstract}
Although the active ageing concept generally has positive connotations, with expected benefits at the micro, meso and macro levels, the application of this concept in terms of policy making presents challenges and risks to be avoided (for instance, a predominantly productivist interpretation and a top-down imposition with limited possibilities for bottom-up exchanges; or a disregard for the risk of excluding older people with more disadvantaged backgrounds). Two crucial strategies to minimise risks are the implementation of policies by considering and respecting territorial diversity, and the involvement of all the relevant stakeholders in a participatory consultative and co-decisional approach. This paper entwines both strategies together by focusing on Italian in-country differences in terms of active ageing, and employing the Active Ageing Index for policymaking purposes. This activity is part of a governmental national pilot project aimed at promoting multilevel co-managed co-ordination of active ageing policies across Italy. The analysis identified five groups of regions that differ from the classical, geographic and socio-economic division between the North, Centre and South. Additional ingroup analyses were conducted to investigate within-cluster differences. This study will inform a large multilevel stakeholder network for evidence-based policies and their monitoring at both the national and regional levels, in line with the perspective of mainstreaming ageing.
\end{abstract}

Keywords: Active Ageing Index; mainstreaming ageing; stakeholder involvement; participatory approach; regional diversity

\section{Introduction: the concept of active ageing}

The concept of active ageing has been promoted at the European policy level (López-López and Sánchez, 2020) for several years. Evidence suggests that its

(C) The Author(s), 2021. Published by Cambridge University Press. This is an Open Access article, distributed under the terms of the Creative Commons Attribution licence (http://creativecommons.org/licenses/by/4.0/), which permits unrestricted re-use, distribution and reproduction, provided the original article is properly cited. 
implementation can positively impact the micro, meso and macro levels. At the micro level, it contributes to improving the quality of life, wellbeing, and physical and mental health of older individuals; at the meso level, it allows organisations (e.g. companies and the Third Sector) to benefit from the contribution and experience of older people in formal and non-formal activities. Lastly, its implementation may also have positive effects at the macro-societal level, as healthier and more engaged older people may reduce inequalities and save public spending in several ways, including in the field of public health and expenditure on pensions (Walker, 2011; Lamura et al., 2019).

\section{Academic debate}

The active ageing concept can be traced back to 1961 and Havighurst's first definition of successful ageing and activity theory (Havighurst, 1961), which countered the widespread view of the disengagement theory (Cumming and Henry, 1961) and underlined adherence to the activities and attitudes of middle-aged people to maintain the highest level of satisfaction and happiness (Petretto et al., 2016). In the 1990s, there was a general shift towards positive approaches to ageing, shifting the discourse away from the strict successive phasing of the lifecourse with universal and inevitable dependency, decline and loss in later stages (Boudiny, 2013), and towards ongoing participation and multiple contributions of older people: healthy ageing (World Health Organization (WHO), 1990), successful ageing (Rowe and Kahn, 1987, 1997), optimal ageing (Palmore, 1995), ageing well and others (for a more detailed description of the development of the concepts and multiple definitions, see Bowling, 2005).

Active ageing is a concept that differs from others in a multi-component dynamic approach, taking into account both the individual's life events and the social and structural factors that influence ageing, going beyond purely economic terms towards a holistic approach that includes quality of life, mental and physical wellbeing, and the social participation of older people (Foster and Walker, 2015). In contrast to successful ageing, prioritising the achievement of clinical and medically inspired criteria over social aspects (Foster and Walker, 2015), to embrace the active ageing concept, would mean that experiencing losses in later life, such as poorer health or disability, would not prevent people from reaching positive outcomes in terms of potential and would not undermine older adults' agentic capacities.

Due to multiple definitions and wide usage of the concept of active ageing, several associated risks are acknowledged in the academic literature (Pfaller and Schweda, 2019), the most common being rooted in outdated interpretations of active ageing as a predominantly productivist concept (i.e. primarily promoting longer employment participation and overlooking other types of societal contributions; Barrett and McGoldrick, 2013). An equally common risk is to impose one and only one way of ageing, as well as the obligation of ageing actively, which does not leave room for heterogeneity of preferences, aspirations and individual motivations (Principi et al., 2020a). The latter is linked to the more general risk of adopting a top-down approach (Stenner et al., 2011) when policy makers try to operationalise active ageing. A further challenge relates to the difficulty of being inclusive towards older people with more disadvantaged backgrounds, 
which leads to an uneven distribution of active ageing opportunities. Older people with fewer resources face considerable barriers to active ageing, being deprived of the right to an enabling environment for ageing actively (Li and Ferraro, 2006; Thomas, 2011; Principi et al., 2016a, 2016b). These and other risks ought to be avoided in terms of misleading interpretations of the active ageing concept and, perhaps more importantly, when shifting from the theory of active ageing to policy making in this field.

\section{Active ageing in the political agenda}

Along with the academic debate, active ageing has also emerged as a political line on the agendas of international organisations and European Union (EU) institutions. A milestone in this respect was represented by the European policy document Towards a Europe for All Ages (European Commission, 1999), which was highly employment-oriented, aiming mostly to raise employment rates in older age, to delay retirement and to combat age discrimination in the workplace (Foster and Walker, 2021). The effort by European institutions in trying to operationalise active ageing mostly in productivistic terms was still predominant in the first decade of the new century (European Commission, 2009). From 2010, in line with the WHO's perspective (WHO, 2002), EU documentation started to expand the measures promoting the activation of older people in domains other than just employment, for instance, in lifelong learning, volunteer work and intergenerational practices (European Council, 2010). From 2012, the European year dedicated to active ageing and solidarity between generations, institutional orientation to a more comprehensive approach to active ageing became common (Foster and Walker, 2015). In the same year, the United Nations Economic Commission for Europe (UNECE) and the European Commission joined efforts to develop the Active Ageing Index (AAI), ${ }^{1}$ a tool for measuring active ageing multi-dimensionally.

\section{Measuring active ageing}

The AAI was designed as an evidence-based tool for policy making to further promote active ageing at the pan-European level, and to evaluate and monitor active ageing outcomes at the national and local levels, taking into account the distinctiveness and characteristics of different geo-governmental and socio-economic contexts. This index measures the level to which older men and women participate in paid employment and various social activities, enjoy independent lives, and the extent to which the environment enables their active ageing. The AAI is based on 22 outcome and context indicators, each presenting a positively defined coefficient ranging from 0 to 100 , where 100 is the theoretical maximum of potential realised in the chosen field. The index focuses on people aged 55 and over. The individual scores of indicators are grouped with a weighting mechanism into four domains. The Employment domain consists of four age-group employment rate indicators. Participation in society involves voluntary activity, caring for children and other adults, and political participation. Independent, healthy and secure living includes physical activity, access to health services, financial security, physical safety and lifelong learning. The final domain, Capacity and enabling environment 
for active ageing, includes remaining life expectancy (and the proportion of life in good health), mental wellbeing, use of information and communications technology, social connectedness and educational attainment. The domain scores can be combined into a single overall score, representing the general degree of realisation of older people's active ageing in a specific geographical context.

One of the AAI's generally recognised strengths is its contribution to sensitising people, including policy makers, to the multi-dimensionality and complexity of active ageing (São José et al., 2017). Still, several challenging aspects of the AAI should be addressed to maximise the tool's usefulness in delivering policy-making messages.

The first challenging aspect is that the AAI measures the level of involvement in activities. However, it does not consider how older people value or want to be engaged in these activities, which could be regarded as a weakness if AAI results aspire to inform policy making directly (São José et al., 2017). The way to face this challenge is to implement a participatory approach and to involve older people, and/or the people and entities representing them, in consultative or co-decisional policy-making processes concerning active ageing (Barbabella et al., 2020a), based on the analysis of the AAI results. It is important to note that, in this perspective, the AAI is mentioned in legislation for promoting active ageing through a participatory approach. For instance, the Regional Law on Active Ageing, enacted by the Italian Marche Region, includes the AAI as one of the possible policy monitoring tools, while also establishing a 'permanent regional committee on active ageing' involving, in addition to policy makers, a range of stakeholders from civil society (Marche Region, 2019).

The involvement of all relevant stakeholders from civil society in subsequent policy making would also provide an opportunity for wellbeing and quality of life to be considered as an outcome of active ageing, if not explicitly (the AAI does not directly measure this), at least implicitly. The participatory and co-designing approaches would also mitigate other critical aspects. For instance, it would mitigate the effect of possible arbitrariness (São José et al., 2017) in methodological choices concerning the index and help avoid direct comparisons and benchmarking (Marsillas Rascado, 2019).

The index was originally presented as a way to measure 'the untapped potential of older people' (Zaidi and Stanton, 2015), thus underlining an extremely productivist view, as well as an unrealistic exercise (São José et al., 2017). Acknowledging the difficulty of fully avoiding a 'normative' use of the AAI when applied in multiple contexts, this weakness may be mitigated by pursuing a more practical use of this tool by concentrating on the deviations of the single domains from the average score. This could be done across countries (Lamura et al., 2019), for instance, to identify those with similar situations in terms of active ageing, to recognise challenges in policy areas for possible intervention and for the exchange of best practices. The same exercise could be carried out at the national level, for instance, by investigating regions in order to identify areas where appropriate policies can create an enabling environment to realise the active potential of older people, with goalposts which could (or should) be different across regions, depending on the geographical, cultural, social and economic contexts. 
A further challenge refers to the fact that the AAI, as originally planned, only presented a breakdown by gender. Under these conditions, it is difficult to respond to the need to deliver policy insights on how to involve older people with fewer resources and, thus, facing more barriers to active ageing (São José et al., 2017). Although the AAI's easily replicable and transparent methodology provides possibilities to disaggregate the index beyond gender, it is essentially a question of data availability, since the sources employed to build the AAI (Zaidi et al., 2013) did not allow for other breakdown results. However, the index can be adapted to other existing sources, for example, at the subnational level or by using unique national data (UNECE and European Commission, 2018). This may provide more details in terms of data specificity and may yield results with a breakdown by other important variables, for example, the educational level, income, living place, family typology, etc. (Bauknecht et al., 2017; Perek-Białas et al., 2017; Principi et al., 2019).

\section{Diversity in active ageing}

Active ageing policies and monitoring tools should also respect national and cultural diversity (Foster and Walker, 2015). Older people's values and goals relative to active ageing dimensions may vary considerably depending on the studied context, culture and traditions (Timonen, 2016). At the country level, culture shapes the welfare regime (Principi et al., 2014), and diversity can either refer to differences between countries or those within the country. The latter can be associated with regional differences, which must be taken into account.

On the one hand, regional diversity means that the commonly recognised barriers to experiencing active ageing (i.e. poor physical and mental health, low socioeconomic status, etc.) may be much more pronounced or harmful in certain local contexts than in others. A lack of resources may affect the micro level, but also the societal level, for instance, in terms of wealth, social capital, or the availability of public services and infrastructure. On the other hand, values, individual motivations and aims, in terms of active ageing, may differ across subnational contexts. For example, it may be more common to exercise active ageing through employment in some contexts. In others, it would be more commonly done through grandparenting, volunteering or other activities. Furthermore, attitudes towards intergenerational exchange may be different. As Villar (2012) pointed out, social and cultural settings contextualise individual ageing and vary considerably in terms of the demands they involve and the opportunities and resources they offer. Therefore, evaluating and monitoring active ageing determinants and outcomes at the regional level acquires special importance, and the AAI provides such an opportunity.

\section{The $A A I$ at the regional level}

Previous regional applications of the AAI were successfully conducted in Poland and Spain. While the AAI is mentioned in various policy documents in other countries, its regional implementation is usually still not considered or performed. In some cases, it is explained by the countries' small sizes, having no reason for regional investigation; as is the case, for example, of Malta, Slovenia and Latvia 
(National Commission for Active Ageing, 2014; Cabinet of Ministers, 2016; IMAD, 2018). In some cases of national policy documents dealing with the management of active ageing, the index was mentioned but still not implemented, as in Bulgaria (Naydenova, 2019), or was not mentioned at all, as in the Czech Republic and Ireland (Department of Health, 2013; MPSV, 2014). Although the regional AAI has not been calculated for the whole of Germany (Karpinska and Dykstra, 2015), a study was conducted investigating 30 German NUTS (Nomenclature des Unités Territoriales Statistiques - Nomenclature of Territorial Units for Statistics) 3 territories, broadly corresponding to the provincial-territorial level (Bauknecht et al., 2016). The study aimed to deliver insights for local policy makers and stakeholders, even though there was no clear link with them in concrete terms.

As mentioned, an experiment funded by the Ministry of Family, Labour and Social Policy was held in Poland in order to apply the AAI at the regional level, and design active ageing policies. The relevant reports are available in Polish, although this experiment was reported in Perek-Bialas et al. (2017). The Polish study used regional mapping to visualise the situation at the regional level with regard to the overall and domain scores, with the possibility of identifying groups of regions with a similar score. However, the Polish exercise lacks an attempt to promote bottom-up participation in the discussion on policy making. Furthermore, the lack of adequate national data sources resulted in quite different indicators than the original AAI. Another AAI application at the regional level was performed in Spain (Marsillas Rascado, 2019). Similar to the Polish study, but without the use of maps, the Spanish attempt was based on a regional ranking regarding the overall and domain scores. The study provides recommendations for improvements at the regional level to be used by policy makers and other stakeholders.

In this respect, the main gaps in current knowledge are related to the fact that the 'classic' ranking-related approach, characterising existing AAI studies at the regional level, hinders the full use of the richness of the analysis results for evidence-based policy making, e.g. not facilitating the delivery of focused inputs for resource allocation at the central governmental level to the regions.

\section{Italy: a remarkably diverse and unequal country}

Regional differences are especially pronounced in Italy, as they are rooted in historical territorial divisions and autonomies (Putnam, 1993). The remaining portion of this section will illustrate why Italy represents a good example for stressing the need for regional AAI implementation.

The Italian welfare state is analysed and categorised as belonging to the Mediterranean model, homogeneously characterised by a family-based welfare model with very limited public responsibilities (Ferrera, 1996). However, Italy is a country with significant regional variations. Primarily, in geomorphological terms, as it includes both Europe's highest mountain regions and large fertile plains, as well as extremely long coastal areas, major islands and different climatic zones. All this geo-climatic variety, combined with the highly differentiated historical background of the individual regions, is reflected and linked to wide diversity in terms of socio-economic characteristics and cultural attitudes. 
After the proclamation of the unification of Italy in 1861, less than 10 per cent of citizens could speak the national language. Regional differences were seen as the main obstacle to national development, due to different contexts in economic, social, cultural and political terms, with the evident backwardness of the southern part of Italy (Putnam, 1993; Federico et al., 2019). At that time, a strong central authority was judged as the best way to pursue a new national identity, including prosperity and political progress, where the separate parts struggled to fit in (Ghisalberti, 1986). The aspiration for regional decentralisation and power to maintain regional identity was always in the background and started to be manifested, especially after the Second World War, with dissatisfaction towards excessive centralism. The new Constitution in 1948 established popularly elected regional governments (Leonardi et al., 1981). However, apart from five regions having special forms and conditions of autonomy created shortly after the Second World War, ${ }^{2}$ due to strong obstructionism by conservative parties against decentralisation of power, the first regional elections in 15 regions with ordinary status only took place in 1970, the year of their establishment. In the 1970s, from the point of view of political administration, travelling from one Italian place to another could mean going back in time through the centuries (Putnam, 1993).

Decentralisation may have various meanings. Positively speaking, it may mean respecting regional diversity and differences, however, some regions could be left behind. Regional governments have been the primary decision makers in a variety of political spheres since the 1990s, including urban planning, agriculture, health, public works and vocational training, among others (Putnam, 1993). An important further step towards decentralisation was undertaken with the 2001 constitutional reform, which expanded the power of regions, especially in terms of legislative power. With some exceptions, regions can now legislate on a wide range of subjects, in some cases in the form of legislative competence shared by both the state and the regions (Groppi and Scattone, 2006). This includes most, if not all, dimensions afferent to the concept of active ageing (Barbabella et al., 2020b). This reform underlined the richness of Italian regional diversity, which is currently still clearly visible (Felice, 2018).

Figure 1 presents data for some selected indicators to highlight current Italian regional diversity: the share of the older population, economic development (Gross Domestic Product (GDP) and pension amount), perceived life satisfaction and health-related indicators, such as the presence of multimorbidity and the outreach of formal home care services across regions. The last two proposed indicators concern environmental factors, that is, the share of the population living in urban contexts and the use of public transportation.

Some regions in northern and central Italy (Liguria, Friuli-Venezia Giulia, Piedmont, Umbria and Tuscany) have the highest share of older people among the population, while the lowest share is mostly in the South $(18.8 \%$ in Campania), with the exceptions of the northern Autonomous Province (AP) of Bolzano and the central Italian region of Lazio.

With some exceptions, the more favourable active ageing values of the indicators are concentrated in the northern part of Italy, with a mixed situation in the centre and more challenging cases in the southern regions. 


\begin{tabular}{|c|c|c|c|c|c|c|c|c|c|}
\hline & Region & $\begin{array}{l}\text { Share of } \\
\text { population } \\
\text { aged } 65+ \\
\text { (a) }\end{array}$ & $\begin{array}{l}\text { GDP } \\
\text { (b) }\end{array}$ & $\begin{array}{c}\text { Average } \\
\text { pension } \\
\text { amount } \\
\text { (c) }\end{array}$ & $\begin{array}{l}\text { Life } \\
\text { satisfaction } \\
\text { (d) }\end{array}$ & $\begin{array}{c}2+ \\
\text { chronic } \\
\text { diseases } \\
\text { (e) }\end{array}$ & $\begin{array}{c}\text { Formal } \\
\text { home } \\
\text { care } \\
\text { (f) }\end{array}$ & $\begin{array}{c}\text { Urban } \\
\text { population } \\
\text { (g) }\end{array}$ & $\begin{array}{c}\text { Public } \\
\text { transport } \\
\text { (h) }\end{array}$ \\
\hline \multirow{10}{*}{$\begin{array}{l}\frac{5}{\mathrm{t}} \\
\text { z }\end{array}$} & Piedmont & 25.5 & 31.4 & 15,168 & 7.1 & 18.0 & 0.7 & 25.2 & 18.3 \\
\hline & Aosta Valley & 23.8 & 38.9 & 14,564 & 7.3 & 19.4 & 3.8 & 0.0 & 14.8 \\
\hline & Lombardy & 22.6 & 38.8 & 15,575 & 7.2 & 19.8 & 1.2 & 40.8 & 23.5 \\
\hline & AP Bolzano & 19.6 & 47.0 & 14,887 & 7.8 & \multirow{2}{*}{$16.1^{1}$} & 4.3 & 20.3 & 25.1 \\
\hline & AP Trento & 22.1 & 38.1 & 14,705 & 7.5 & & 2.2 & 21.9 & 21.8 \\
\hline & Veneto & 22.9 & 33.2 & 14,587 & 7.2 & 19.3 & 1.1 & 18.9 & 14.6 \\
\hline & Friuli & & & & & & & & \\
\hline & $\begin{array}{l}\text { Venezia } \\
\text { Giulia }\end{array}$ & 26.2 & 31.3 & 15,119 & 7.1 & 19.4 & 2.0 & 29.2 & 19.8 \\
\hline & Liguria & 28.5 & 32.2 & 15,525 & 7.2 & 20.9 & 0.9 & 50.7 & 32.3 \\
\hline & $\begin{array}{l}\text { Emilia } \\
\text { Romagna }\end{array}$ & 23.9 & 36.2 & 14,656 & 7.1 & 19.8 & 1.2 & 36.0 & 13.4 \\
\hline \multirow{4}{*}{ 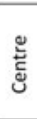 } & Tuscany & 25.4 & 31.5 & 14,749 & 7.1 & 17.4 & 0.6 & 27.2 & 14.3 \\
\hline & Umbria & 25.6 & 25.2 & 14,147 & 7.0 & 22.4 & 0.3 & 31.4 & 9.9 \\
\hline & Marche & 24.8 & 28.0 & 13,326 & 7.1 & 18.7 & 0.5 & 12.9 & 13.3 \\
\hline & Lazio & 21.7 & 33.5 & 17,565 & 6.8 & 21.0 & 0.8 & 50.7 & 29.3 \\
\hline \multirow{9}{*}{ 壱 } & Abruzzo & 23.8 & 25.5 & 13,280 & 7.0 & 22.3 & 1.0 & 9.1 & 14.7 \\
\hline & Molise & 24.6 & 20.6 & 12,290 & 6.8 & 20.0 & 2.0 & 16.0 & 17.7 \\
\hline & Campania & 18.8 & 18.5 & 14,204 & 6.6 & 22.8 & 0.6 & 59.6 & 21.2 \\
\hline & Apulia & 22.1 & 18.6 & 13,908 & 6.9 & 21.7 & 0.6 & 21.4 & 18.2 \\
\hline & Basilicata & 23.0 & 21.8 & 12,332 & 7.1 & 21.2 & 0.9 & 22.6 & 22.9 \\
\hline & Calabria & 21.6 & 16.9 & 12,762 & 6.9 & 25.0 & 0.6 & 17.3 & 18.0 \\
\hline & Sicily & 21.2 & 17.6 & 14,255 & 6.9 & 22.9 & 0.9 & 27.6 & 15.0 \\
\hline & Sardinia & 23.8 & 21.0 & 14,303 & 7.1 & 24.6 & 1.9 & 17.1 & 15.6 \\
\hline & Italy & 22.8 & 29.2 & 14,874 & 7.0 & 20.5 & 1.0 & 33.4 & 18.1 \\
\hline
\end{tabular}

Figure 1. Characteristics of Italian regions based on exemplary indicators.

Notes: Values of the indicators that exceed one standard deviation from the Italian value are highlighted in green; the values below the mean by more than one standard deviation are in red. 1. Data available only for the region Trentino Alto Adige as a whole (including both Autonomous Provinces of Bolzano and Trento). (a) Percentage of 65+ population, 2019 (ISTAT, 2019a). (b) Gross Domestic Product pro capita, 2018, thousands of euros (ISTAT, 2020a). (c) Average amount of old-age pensions (includes also pensions for indemnification and survivor's pensions) in euros, 2017 (ISTAT, 2019a). (d) Average self-rated life satisfaction 14+ population in 2018: range from $0=$ lowest satisfaction to 10 = highest satisfaction (ISTAT, 2019a). (e) Standard rate of two or more chronic diseases among the population, 2014-2015 (ISTAT, 2019b). (f) Percentage of home care 65+, 2017 (ISTAT, 2020b). (g) Share of population living in highly urbanised contexts in 2018 (ISTAT, 2019a). (h) Percentage of people using public transportation on people using means of transportation for reasons of work or study 2019 (ISTAT, 2020b).

The highest GDPs are in the North (€47,000 pro capita in the AP of Bolzano), with the lowest in Calabria $(€ 16,900)$ within a group of southern regions with quite low values. Similar circumstances apply to the average pension income, with the southern regions of Molise, Basilicata and Calabria having very low pensions on average, and the northern regions in a much better situation. The highest pensions, however, are found in Lazio (central Italy).

Self-rated life satisfaction is higher in the northern than in the southern regions. However, one of the worst values in this respect is reported in the Lazio region (central Italy).

With regard to health aspects, again, a better situation is seen in the North. Multimorbidity is especially prevalent in the South (in Calabria, 25\% of the population has two or more chronic diseases), and Umbria in central Italy is also in this unfavourable situation. Home care services for older people are more frequently 
featured in northern regions (4.3\% in AP of Bolzano) than in the central and southern regions. In this respect, Molise is an outsider among the southern regions, with a good diffusion of formal home care services, compared to the national average.

As regards environmental aspects, the picture is less defined in geographical terms. For instance, the share of the population living in urban contexts is very high in Campania (South), Lazio (Centre) and Liguria (North). In contrast, it is absent in the Aosta Valley (North), and it is very low in Abruzzo (South) and Marche (Centre). The use of public transport more or less follows the same trend.

Therefore, although the division of Italian regions into the South-Centre-North is still relevant, the selected indicators show inequalities and diversity going beyond this classical tripartite model. This represents a very good case worth investigating in terms of active ageing through the employment of the AAI at the regional level.

\section{Aims of the paper}

In light of the above, this study's main hypothesis is that inequalities across Italian regions in terms of active ageing occur beyond the classical tripartite Italian geographical division (North, Centre, South). To explore these inequalities by also addressing the identified gaps in knowledge, the novelty of this study would be to adopt cluster analysis for a more practical use of the AAI at the regional level. Indeed, the cluster analyses proposed in this study advocate a more practical use of the tool by concentrating on domains' deviations from the national average at the regional level, thus ensuring clear messages for the politically relevant governance levels. By shifting attention from the ranking-based analysis to a more problem-focused analysis, this approach aims to more easily identify clusters of regions according to the similarity or dissimilarity of the four AAI main domains, assisting in the better recognition of challenges in policy areas for possible intervention. The results of this study would be useful for discussion with national and regional policy makers, as well as with other relevant stakeholders from civil society, within an ongoing national initiative to adopt multilevel co-ordination of active ageing policies in Italy (Barbabella et al., 2020a). The planned stakeholder involvement would minimise as much as possible the risks associated with the operationalisation of the active ageing concept, as discussed above, through policy making. The study could be considered as an Italian pilot experience to inspire other countries or geographical contexts to adopt similar experiences and research approaches.

\section{Methods}

Microdata from the national surveys of the National Institute of Statistics (ISTAT), that are representative of the Italian population, were used to build the AAI specifically for this study (hereinafter, AAI-IT ${ }^{3}$ ). The main goal in building the index was to reduce as much as possible the discrepancies from the original UNECE Active Ageing Index (hereinafter, AAI-EU). Out of 22 indicators, 13 (from the sources EU-Statistics on Income and Living Conditions (EU-SILC), Labour Force Survey (LFS) and Mortality Tables) were the same as the AAI-EU. The remaining nine were taken from the Italian ISTAT surveys on Aspects of Daily Life (ADL), Family and Social Subjects (FSS) and the European Health Interview Survey 
(EHIS), according to the recommendations of the Guidelines on the calculation of the AAI at the subnational level (UNECE and European Commission, 2018). The discrepancies between the AAI-IT and AAI-EU (Table 1) resulted in a generalised underestimation of the overall score (and particularly the second domain's score: Participation in society) in the AAI-IT compared to the AAI-EU. For example, in indicators 2.2 (care to children and grandchildren) and 2.3 (care to older adults), the AAI-EU considers care independent of co-habitation status, while the AAI-IT only considers non-co-habiting care. A detailed description of the interplay between possible underestimations and overestimations, due to differences in each indicator, is available in Principi et al. (2020b).

Since some of the surveys used to build the AAI-IT were not carried out in 2018, the usage of data from other years (minimising the time gap) was unavoidable in a few cases. For instance, the FSS survey was conducted in 2016 (indicators 2.2 and 2.3), and the EHIS was conducted in 2013 and 2015 (indicator 4.3).

The annual EU-SILC survey is an exception. The ISTAT did not continue to release the variable concerning the region (NUTS 2) from 2016 onwards. Therefore, to develop the AAI for 2018, there was no option but to use EU-SILC 2015 data. The same happened with EHIS 2015 data: the variable region was not released, so we were forced to use 2013 data for the year 2018 (indicator 4.3).

A supplemental challenge was caused by several Italian survey questions, which were exactly the same as the questions used in the AAI-EU. However, the ISTAT did not release the variables concerned because they were not valid (Principi et al., 2020b). For example, this influenced indicator 3.7 (physical safety). In the 2018 ADL questionnaire, a question was very similar to the AAI-EU question. However, the ISTAT did not release data for 2018, thus, another variable was used concerning the investigation of perceptions on the risk of crime in the area, rather than the perceived feeling about walking alone in the respondent's local area or neighbourhood after dark. This also affected indicator 4.4: for 2018, the variable on internet use 'in the last three months' was not released by the ISTAT, so the 'last 12 months' were investigated instead.

Despite these challenges, it was possible to estimate an index that is ultimately similar to the original AAI-EU.

An additional relevant point for this study relates to two specifications on the dataset concerning the variable 'region'. (a) The Trentino-Alto Adige region is made up of two APs: Bolzano and Trento. We could not include the latter's level of detail in this study since some sources (ADL, FSS and LFS) did not release the data of each of the two APs. For this reason, we did not investigate the Bolzano and Trento APs separately, but rather as the combined region of Trentino-Alto Adige. (b) Aosta Valley is the smallest Italian region (126,000 inhabitants). In some cases, the ISTAT did not release microdata for this region, but merged them with Piedmont's data. As a consequence, the latter regions are merged in this study.

Full methodological details concerning the construction of the AAI-IT can be found in Principi et al. (2020b). Only the AAI-IT results are described later on in the study. Therefore, the AAI refers to the Italian case. 
Table 1. Differences between indicators of the Italian Active Ageing Index (AAI-IT) and the original Active Ageing Index (AAI-EU)

\begin{tabular}{|c|c|c|}
\hline Domain and indicator & AAI-EU ${ }^{1}$ & AAI-IT \\
\hline \multicolumn{3}{|l|}{ Domain 1: Employment: } \\
\hline 1.1. Employment rate 55-59 & No difference (LFS) & \\
\hline 1.2. Employment rate $60-64$ & No difference (LFS) & \\
\hline 1.3. Employment rate $65-69$ & No difference (LFS) & \\
\hline 1.4. Employment rate $70-74$ & No difference (LFS) & \\
\hline \multicolumn{3}{|l|}{$\begin{array}{l}\text { Domain 2: Participation in } \\
\text { society: }\end{array}$} \\
\hline 2.1. Voluntary activities & $\begin{array}{l}\text { How often }\left(55^{+}\right) \text {did you do unpaid voluntary work through } \\
\text { the following organisations in the last } 12 \text { months? [list of } \\
\text { organisations] } \\
\text { Every week; Every month; Less often/occasionally; Not at } \\
\text { all. (EQLS) }\end{array}$ & $\begin{array}{l}\text { Did you }(55+) \text { do unpaid voluntary work for voluntary } \\
\text { associations or groups in the last } 12 \text { months? Yes; No. (ADL) }\end{array}$ \\
\hline $\begin{array}{l}\text { 2.2. Care to children and } \\
\text { grandchildren }\end{array}$ & $\begin{array}{l}\text { In general, how often are you involved in any of the } \\
\text { following activities outside paid work? (a) Caring for and/or } \\
\text { educating your children; (b) Caring for and/or educating } \\
\text { your grandchildren } \\
\text { (Every day; Several days a week; Once or twice a week; } \\
\text { Less often; Never) (EQLS) }\end{array}$ & $\begin{array}{l}\text { Did you provide some of the following types of unpaid help } \\
\text { to individuals (relatives and not) that do not live with you, } \\
\text { in the last four weeks? (multi-response, concerning } 11 \\
\text { possible types of help): care and assistance to children. } \\
\text { (FSS) }\end{array}$ \\
\hline 2.3. Care to older adults & $\begin{array}{l}\text { In general, how often are you involved in any of the } \\
\text { following activities outside paid work? (d) Caring for } \\
\text { disabled or infirm family members, neighbours or friends } \\
\text { under } 75 \text { years old; (e) Caring for disabled or infirm family } \\
\text { members, neighbours or friends aged } 75 \text { or over (Every day; } \\
\text { Several days a week; Once or twice a week; Less often; } \\
\text { Never) (EQLS) }\end{array}$ & $\begin{array}{l}\text { Did you (55+) provide some of the following types of unpaid } \\
\text { help to individuals (relatives and not) that do not live with } \\
\text { you, in the last four weeks? (multi-response, concerning } 11 \\
\text { possible types of help): care and assistance to adult } \\
\text { individual (help in washing, dressing, eating, etc.). (FSS) }\end{array}$ \\
\hline 2.4. Political participation & $\begin{array}{l}\text { Over the last } 12 \text { months, have you }(55+) \ldots ? \text { (a) Attended a } \\
\text { meeting of a trade union, a political party or political action }\end{array}$ & $\begin{array}{l}\text { Did you }(55+)(\text { a) participate in meetings of a trade union, } \\
\text { political party, ecological associations, for civil rights or for }\end{array}$ \\
\hline
\end{tabular}


Table 1. (Continued.)

\begin{tabular}{l} 
Domain and indicator \\
\hline \\
Domain 3: Independent, healthy \\
and secure living:
\end{tabular}

and secure living: group; (b) Attended a protest or demonstration; (c) Signed a petition, including an email or online petition; (d)

Contacted a politician or public official (other than routine contact arising from use of public services) Yes; No. (EQLS) peace; (b) in a rally or a protest demonstration; (c) not included; (d) not included; in the last 12 months? Yes; No. (ADL)

How frequently do you (55+) do each of the following? (c) Take part in sports or physical exercise. Every day or almost every day. (EQLS)
Do you (55+) practise one or more type of sports

continuously, or do you do physical activity (e.g. walking at least two kilometres, swimming, cycling or other) one or more times a week? Yes; No. (ADL)

\subsection{Access to health services \\ 3.3. Independent living \\ 3.4. Relative median income \\ 3.5. No poverty risk \\ 3.6. No material deprivation \\ 3.7. Physical safety}

3.8. Lifelong learning

No difference (EU-SILC)

No difference (EU-SILC)

No difference (EU-SILC)

No difference (EU-SILC)

No difference (EU-SILC)

'How safe do you (55+) - or would you - feel walking alone in this area (Respondent's local area or neighbourhood) after dark? Do - or would - you feel' Very safe; Safe. (ESS)

Does the living area of your family have crime risks? Few; Not at all. (ADL)

Domain 4: Capacity and

enabling environment for active ageing:
4.1. Remaining life
No difference (Mortality Tables)
expectancy at age 55
4.2. Share of healthy life
expectancy at age 55
No difference (Mortality Tables + EU-SILC) 


\subsection{Mental wellbeing}

(1)

Over the last two weeks (55+):

(1) I have felt cheerful and in good spirits.

(2) I have felt calm and relaxed.

(3) I have felt active and vigorous.

(4) I woke up feeling fresh and rested.

(5) My daily life has been filled with things that interest me.

Response categories of each of these five survey questions are:

(1) All of the time.

(2) Most of the time.

(3) More than half of the time.

(4) Less than half of the time.

(5) Some of the time.

(6) At no time.

The raw score is calculated by reversing the value order of the variable, and then totalling the figures of the five answers. The raw score is converted so as to range from 0 to 25,0 representing worst possible and 25 representing best possible quality of life. According to the WHO, a raw score below 13 indicates poor wellbeing and is an indication for testing for depression under the Major

Depression (ICD-10) Inventory. (EQLS and the WHO's ICD-10 measurement model)

4.4. Use of ICT

How often on average have you (55-74) used the internet in the last three months? Every day or almost every day; At least once a week (but not every day). (Eurostat ICT survey)

4.5. Social connectedness

How often do you (55+) meet socially with friends, relatives or colleagues? Once a week; several times a week; every day. (ESS)
In the last 4 weeks you (55+) felt:

(1) Happy.

(2) Calm and/or peaceful.

(3) Full of energy.

(4) Very down to earth (scale reversed).

(5) Discouraged and sad (scale reversed).

Response categories of each of these five survey questions are:

(1) Always $=5$

(2) Almost always $=4$.

(3) A lot of time $=3$.

(4) Some of the time $=2$

(5) Almost never $=1$.

(6) Never $=0$.

The range is from 0 to 25,0 representing worst possible and 25 representing best possible quality of life, and it has been converted to range from 0 to 100 . (EHIS, from the SF-36 questionnaire - mental health)

How often on average have you (55-74) used the internet in the last 12 months? Every day; Almost every day; Once a week. (ADL)

How often do you (55+) meet friends in your free time? Every day; more than once a week; once a week. (ADL)

4.6. Educational attainment No difference. (LFS)

Notes: LFS: Labour Force Survey. EQLS: European Quality of Life Survey. ADL: Aspects of Daily Life. FSS: Family and Social Subjects. EU-SILC: EU-Statistics on Income and Living Conditions. ESS European Social Survey. WHO: World Health Organization. ICD-10: International Classification of Diseases, 10th revision. ICT: information and communications technology. EHIS: European Health Interview Survey. SF-36: Medical Outcomes Survey 36-item Short Form. 1. In bold, the response categories considered to build the indicators. Full methodological information about all the 22 AAI indicators can be found at https://statswiki.unece.org/display/AAI/IV.+Methodology. 


\section{Statistical analysis}

A hierarchical average-linkage cluster analysis with the Euclidean dissimilarity measure methodology was used to identify regional groups. This analysis was carried out with the aim of detecting the presence of groups of cases within Italian regions that are both similar (i.e. presenting 'maximum similarity') within each group and, at the same time, as different as possible from the other groups (i.e. reflecting the 'highest diversity' between clusters). Such agglomerative procedures first combined all the same characteristic combinations into a cluster. Once they could no longer be combined further, two clusters were fused, increasing internal heterogeneity. This process was performed until the last fusion step, when the last two remaining clusters were merged into one. From this point, the individual fusion steps were reversed to determine, with the inverse screen test, at which step heterogeneity increased erratically (Elbow criterion). In this way, an optimal number of five homogeneous clusters representing five different AAI domain combinations was identified. The indicators used for this analysis were the four AAI domain-specific scores calculated for each region: Employment; Participation in society; Independent, healthy and secure living; and Capacity and enabling environment for active ageing. Data were analysed using the Stata version 15.1 Statistical Software Package for Windows (StataCorp, College Station, TX).

\section{Results}

Table 2 illustrates AAI domain-specific and overall scores captured in Italian regions in 2018. It is possible to observe deviations from the national average scores across regions. In the Employment domain, deviations are from -6.8 to 4.6 (scores from 23.8 to 35.2, national average of 30.6). In the Participation in society domain, deviations are from -3.2 to 4.0 (scores from 6.0 to 13.2, national average of 9.2). Relative to the Independent, healthy and secure living domain, there are deviations from -4.4 to 4.6 (scores from 51.2 to 63.6, national average of 72.3). Lastly, deviations in the Capacity and enabling environment for active ageing domain are from -4.7 to 12.4 (scores from 51.2 to 63.6 , national average of 55.9). The overall score (AAI) shows that regional deviations range from -4.4 to 4.9 with respect to the national average of 32.3 (scores from 27.9 to 37.2 ).

The greater positive deviation is found in the Capacity and enabling environment for active ageing (12.4 in Trentino-Alto Adige), while the greater negative one is in the Employment domain (-6.8 in Sicily).

The second step of analysis aggregates regions in clusters, characterised by similarities in four AAI-IT domain-specific scores. The following rationale is implied: similar cluster-related situations may require similar actions at the policy-making level, making it possible to convey the main messages in an easy to understand manner. By considering each region's four AAI-IT domain-specific scores to obtain clusters as described in the Methods section, the cluster analysis identified five groups of regions with similar characteristics (Figure 2).

Even if preliminary analysis confirms the partial relevance of the tripartite classical geographic division, the five clusters reflect a geographical pattern going beyond the latter. A large group of northern and central regions was identified. However, the northernmost region (Trentino-Alto Adige) forms a cluster per se. 
Table 2. Italian Active Ageing Index (AAI-IT) domains and overall scores, 2018, by region

\begin{tabular}{|c|c|c|c|c|c|}
\hline Region & $\mathrm{E}$ & $\mathrm{P}$ & 1 & C & AAI \\
\hline \multicolumn{6}{|l|}{ North: } \\
\hline Piedmont and Aosta Valley & 31.3 & 9.4 & 74.5 & 55.6 & 32.8 \\
\hline Lombardy & 31.9 & 11.0 & 74.3 & 58.2 & 34.1 \\
\hline Trentino-Alto Adige & 34.7 & 13.2 & 76.9 & 63.6 & 37.2 \\
\hline Veneto & 31.7 & 10.5 & 74.3 & 57.6 & 33.8 \\
\hline Friuli Venezia Giulia & 32.3 & 10.5 & 75.9 & 59.0 & 34.4 \\
\hline Liguria & 33.4 & 7.6 & 74.6 & 56.6 & 33.1 \\
\hline Emilia Romagna & 35.2 & 10.9 & 74.5 & 56.7 & 34.9 \\
\hline \multicolumn{6}{|l|}{ Centre: } \\
\hline Tuscany & 35.2 & 9.3 & 74.4 & 58.4 & 34.7 \\
\hline Umbria & 32.2 & 9.7 & 69.4 & 55.6 & 32.8 \\
\hline Marche & 33.7 & 9.4 & 73.0 & 54.9 & 33.3 \\
\hline Lazio & 33.4 & 8.7 & 71.8 & 58.1 & 33.5 \\
\hline \multicolumn{6}{|l|}{ South: } \\
\hline Abruzzo & 31.6 & 8.2 & 72.0 & 55.6 & 32.2 \\
\hline Molise & 30.7 & 6.8 & 71.5 & 58.7 & 32.0 \\
\hline Campania & 26.1 & 6.0 & 67.9 & 51.5 & 28.3 \\
\hline Apulia & 24.4 & 8.7 & 68.5 & 53.1 & 29.1 \\
\hline Basilicata & 30.4 & 9.4 & 69.9 & 54.9 & 31.9 \\
\hline Calabria & 25.2 & 7.9 & 68.7 & 51.9 & 28.8 \\
\hline Sicily & 23.8 & 7.1 & 67.9 & 51.2 & 27.9 \\
\hline Sardinia & 29.1 & 8.8 & 72.2 & 55.1 & 31.5 \\
\hline Italy & 30.6 & 9.2 & 72.3 & 55.9 & 32.3 \\
\hline
\end{tabular}

Notes: Regions are listed according to the order employed usually by ISTAT, starting from North-Western regions descending to the South and lastly islands. E: Employment domain score. P: Participation in society domain score. I: Independent, healthy and secure living domain score. C: Capacity and enabling environment for active ageing domain score. AAl: overall AAI score.

Another group contains most of the southern regions, while the other two groups mostly include a mix of central and southern Italian regions.

More in detail (Figure 3), the southern white cluster (number 1) includes four regions that all have scores considerably below the national average scores in all the four AAI domains, and especially in the Employment $(-19.4 \%$ from the national score) and Participation in society $(-18.5 \%)$ domains.

The green cluster (number 2), which includes Abruzzo, Umbria, Sardinia and Basilicata is, geographically speaking, the less-homogeneous group. However, it is very homogeneous in terms of cluster scores across AAI domains. The scores are almost perfectly aligned with national domain averages (all just a little lower). 


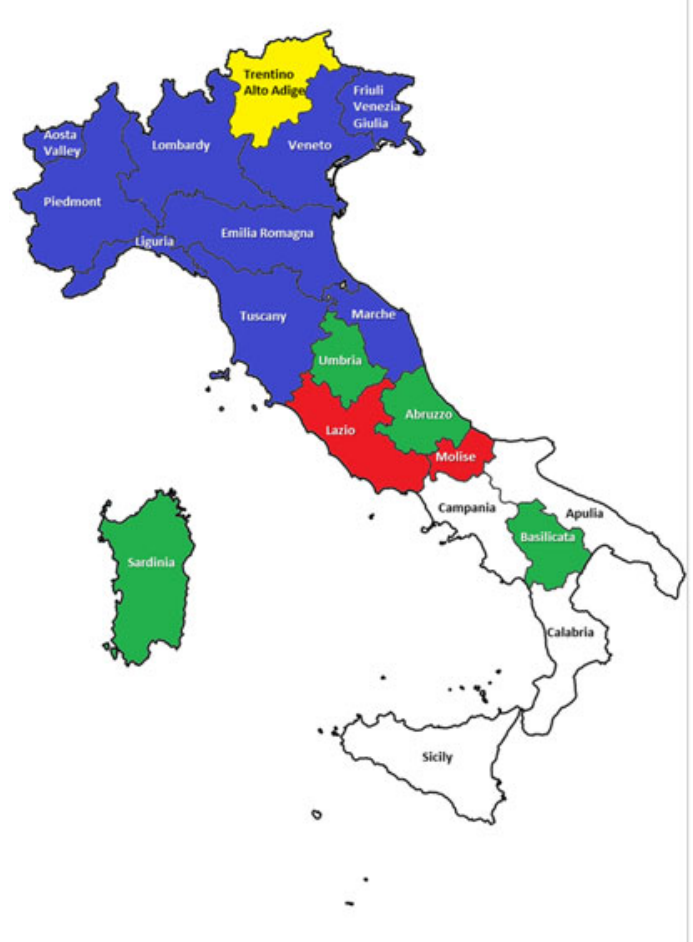

\begin{tabular}{|c|c|}
\hline Region clusters & AAl score \\
\hline 1 & 28.5 \\
\hline 2 & 32.1 \\
\hline 3 & 32.8 \\
\hline 4 & 33.9 \\
\hline 5 & 37.2 \\
\hline
\end{tabular}

Figure 2. Clusters of Italian regions with similar Active Ageing Index (AAI) characteristics.

The third red cluster, which includes Lazio and Molise, is the only one with simultaneously higher or lower scores than the national average. Values are below average especially in the Participation in society domain $(-14.9 \%)$, but also in the Independent living domain, while values are above average in the other two domains.

Cluster four (blue) is the largest one. It includes eight regions and, taking the national average score as a reference point, it is characterised by above-average scores in all the AAI domains, particularly in the Employment $(+7.2 \%)$ and Participation in society $(+7.8 \%)$ domains, showing the reverse picture of the white cluster.

Trentino-Alto Adige (cluster 5, yellow) stands alone, since there are no other regions with such characteristics, namely with well above-average scores in three out of the four AAI domains. The highest positive deviation is in the Participation in society domain with +44.9 per cent with respect to the national average. The remaining AAI domain (Independent living) is also above average, but less than the other three.

Even if clusters help identify similar situations in AAI domain scores that may reflect similar behaviours in terms of policy making, there may be differences within clusters, meaning that challenges and areas of policy intervention may differ in the same cluster. In Figure 4, the previous exercise is repeated by disaggregating 


\begin{tabular}{|c|c|c|c|c|c|c|c|c|c|c|c|}
\hline \multirow[b]{2}{*}{ Cluster } & \multirow[b]{2}{*}{ Region } & \multicolumn{5}{|c|}{ Domain scores } & \multicolumn{5}{|c|}{ Deviation from IT average } \\
\hline & & $E$ & $\mathrm{P}$ & 1 & C & AAI & $E$ & $\mathrm{P}$ & 1 & C & AAI \\
\hline \multirow{4}{*}{1} & Campania & & & & & & & & & & \\
\hline & Apulia & 24.9 & 7.4 & 68.3 & 51.9 & 28.5 & -19.4 & -18.5 & -5.5 & -7.5 & -12.1 \\
\hline & Calabria & & & & & & & & & & \\
\hline & Sicily & & & & & & & & & & \\
\hline \multirow{4}{*}{2} & Umbria & & & & & & & & & & \\
\hline & Abruzzo & 308 & ח & 709 & 553 & 321 & -01 & -09 & -19 & -15 & -10 \\
\hline & Basilicata & 30.0 & 9.0 & 70.7 & & 32.1 & -0.1 & -0.5 & -1.7 & -1.5 & -1.0 \\
\hline & Sardinia & & & & & & & & & & \\
\hline \multirow{2}{*}{3} & Lazio & 321 & 78 & 717 & 584 & 328 & 39 & -149 & -08 & 41 & 10 \\
\hline & Molise & 32.1 & 1.8 & 71.1 & 58.4 & 32.8 & 3.9 & -14.9 & -0.8 & 4.1 & 1.0 \\
\hline \multirow{8}{*}{4} & Piedmont and Aosta Valley & & & & & & & & & & \\
\hline & Lombardy & & & & & & & & & & \\
\hline & Veneto & & & & & & & & & & \\
\hline & Friuli Venezia Giulia & 331 & 98 & 744 & 571 & 320 & 72 & 78 & 31 & 18 & 5 \\
\hline & Liguria & & 9.8 & 74.4 & $3 / .1$ & 33.9 & 1.2 & 1.8 & 3.1 & 1.8 & 4.5 \\
\hline & Emilia Romagna & & & & & & & & & & \\
\hline & Tuscany & & & & & & & & & & \\
\hline & Marche & & & & & & & & & & \\
\hline 5 & Trentino Alto Adige & 34.7 & 13.2 & 76.9 & 63.6 & 37.2 & 12.5 & 44.9 & 6.5 & 13.3 & 14.7 \\
\hline Total & Italy & 30.9 & 9.1 & 72.2 & 56.1 & 32.4 & & & & & \\
\hline
\end{tabular}

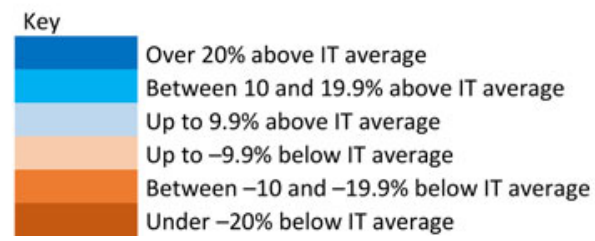

Figure 3. Clusters of Italian (IT) regions with similar Active Ageing Index (AAI) characteristics: clusters' domain and overall scores and deviations from the national average.

Notes: Within clusters, regions are listed according to the ISTAT usually employed order, starting from North-Western regions descending to the South and lastly islands. E: Employment domain score. P: Participation in society domain score. I: Independent, healthy and secure living domain score. C: Capacity and enabling environment for active ageing domain score. AAI: overall AAI score.

regions within each cluster. This helps to link AAI results with the context of the situation, opportunities and policy orientation in the regions. This also makes it possible to better understand each specific region, facilitating the identification of possible policy challenges. This exercise does not concern Trentino-Alto Adige since, as mentioned, this region forms a cluster in itself.

Patterns for the regions belonging to the first white cluster are very similar, except for the score of the Participation in society domain in Apulia, which is closer to the national average. The corresponding domain values are well below average in Sicily and Campania (especially in the latter, with -35.1\%). In the Employment domain, the scores are under -20 per cent compared to the national average in Apulia and Sicily.

The second (green) cluster was characterised by slightly lower scores than the national average in all domains. The disaggregation highlights that Abruzzo is the only region in this cluster with a particularly low score in the Participation 


\begin{tabular}{|c|c|c|c|c|c|c|c|c|c|c|}
\hline \multirow[b]{2}{*}{ Cluster } & \multirow[b]{2}{*}{ Region } & \multicolumn{5}{|c|}{ Domain scores } & \multicolumn{4}{|c|}{ Deviation from IT average } \\
\hline & & $E$ & $\mathrm{P}$ & 1 & C & AAI & $E$ & $\mathbf{P}$ & 1 & C \\
\hline \multirow{4}{*}{1} & Campania & 26.1 & 6.0 & 67.9 & 51.5 & 28.3 & -14.8 & -35.1 & -6.0 & -7.9 \\
\hline & Apulia & 24.4 & 8.7 & 68.5 & 53.1 & 29.1 & -20.1 & -4.8 & -5.2 & -5.1 \\
\hline & Calabria & 25.2 & 7.9 & 68.7 & 51.9 & 28.8 & -17.6 & -13.9 & -4.9 & -7.2 \\
\hline & Sicily & 23.8 & 7.1 & 67.9 & 51.2 & 27.9 & -22.1 & -22.3 & -6.1 & -8.5 \\
\hline \multirow{4}{*}{2} & Umbria & 32.2 & 9.7 & 69.4 & 55.6 & 32.8 & 5.3 & 6.1 & -4.0 & -0.6 \\
\hline & Abruzzo & 31.6 & 8.2 & 72.0 & 55.6 & 32.2 & 3.3 & -10.7 & -0.3 & -0.7 \\
\hline & Basilicata & 30.4 & 9.4 & 69.9 & 54.9 & 31.9 & -0.5 & 2.2 & -3.2 & -1.8 \\
\hline & Sardinia & 29.1 & 8.8 & 72.2 & 55.1 & 31.5 & -4.8 & -3.9 & -0.2 & -1.5 \\
\hline \multirow{2}{*}{3} & Lazio & 33.4 & 8.7 & 71.8 & 58.1 & 33.5 & 9.4 & -5.5 & -0.7 & 3.8 \\
\hline & Molise & 30.7 & 6.8 & 71.5 & 58.7 & 32.0 & 0.3 & -26.4 & -1.1 & 4.9 \\
\hline \multirow{8}{*}{4} & Piedmont and Aosta Valley & 31.3 & 9.4 & 74.5 & 55.6 & 32.8 & 2.5 & 2.6 & 3.1 & -0.6 \\
\hline & Lombardy & 31.9 & 11.0 & 74.3 & 58.2 & 34.1 & 4.4 & 20.1 & 2.8 & 4.1 \\
\hline & Veneto & 31.7 & 10.5 & 74.3 & 57.6 & 33.8 & 3.8 & 14.9 & 2.7 & 3.0 \\
\hline & Friuli Venezia Giulia & 32.3 & 10.5 & 75.9 & 59.0 & 34.4 & 5.6 & 14.0 & 5.0 & 5.4 \\
\hline & Liguria & 33.4 & 7.6 & 74.6 & 56.6 & 33.1 & 9.3 & -17.4 & 3.2 & 1.1 \\
\hline & Emilia Romagna & 35.2 & 10.9 & 74.5 & 56.7 & 34.9 & 15.1 & 18.9 & 3.0 & 1.3 \\
\hline & Tuscany & 35.2 & 9.3 & 74.4 & 58.4 & 34.7 & 15.0 & 1.0 & 2.9 & 4.3 \\
\hline & Marche & 33.7 & 9.4 & 73.0 & 54.9 & 33.3 & 10.2 & 1.9 & 1.1 & -1.9 \\
\hline 5 & Trentino Alto Adige & 34.7 & 13.2 & 76.9 & 63.6 & 37.2 & 13.6 & 43.8 & 6.5 & 13.7 \\
\hline Total & Italy & 30.6 & 9.2 & 72.3 & 55.9 & 32.3 & & & & \\
\hline
\end{tabular}

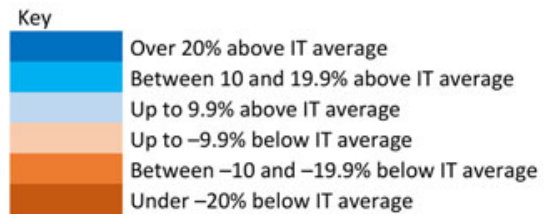

Figure 4. Italian (IT) regions with similar Active Ageing Index (AAI) characteristics: regional domain and overall scores and deviations from the national average.

Notes: Within clusters, regions are listed according to the ISTAT usually employed order, starting from North-Western regions descending to the South and lastly islands. E: Employment domain score. P: Participation in society domain score. I: Independent, healthy and secure living domain score. C: Capacity and enabling environment for active ageing domain score. AAl: overall AAI score.

in society domain $(-17.4 \%)$. In the Employment domain, Umbria and Abruzzo have above average scores, however, Basilicata and Sardinia's scores are below average, especially in the latter region.

The destructuration of the third (red) cluster clarifies that, in the second domain (Participation in society), the score is particularly below average in Molise $(-26.4 \%)$. At the same time, Lazio shows quite a higher score than Molise in the Employment domain.

Turning to the fourth blue cluster, characterised as a group with above-average scores in all AAI domains, we can observe that the most evident singularity is the below-average score $(-17.4 \%)$ of Liguria in the Participation in society domain. It is the only case of a below-average value in this domain relative to this cluster. Lombardy (with $+20.1 \%$ ), Veneto, Friuli-Venezia Giulia and Emilia-Romagna, on the other hand, have significantly higher scores than the national average. Other cases of relatively below-average scores concern Marche and Piedmont/Aosta Valley in the Capacity for active ageing domain. This cluster also presents particularly above-average scores in the Employment domain for the Emilia-Romagna, Tuscany (especially) and Marche regions. 


\begin{tabular}{|c|c|c|c|c|c|c|c|}
\hline Cluster & Region & $\mathrm{E}$ & $\mathrm{P}$ & 1 & $\mathrm{C}$ & AAI & AAl/cluster \\
\hline \multirow{4}{*}{1} & Campania & -19.3 & 0.5 & -1.2 & -4.0 & -7.5 & \multirow{4}{*}{-7.1} \\
\hline & Apulia & -17.0 & -1.6 & 1.3 & -4.0 & -7.2 & \\
\hline & Calabria & -15.2 & -1.8 & 0.8 & -5.6 & -7.0 & \\
\hline & Sicily & -16.1 & -0.5 & 0.7 & -4.6 & -6.7 & \\
\hline \multirow{4}{*}{2} & Umbria & -9.7 & -2.6 & -4.0 & -4.9 & -5.7 & \multirow{4}{*}{-6.2} \\
\hline & Abruzzo & -16.6 & -0.5 & -1.7 & -1.9 & -6.6 & \\
\hline & Basilicata & -17.1 & -2.0 & 0.5 & -3.4 & -7.3 & \\
\hline & Sardinia & -13.6 & 2.2 & -4.7 & -4.0 & -5.3 & \\
\hline \multirow{2}{*}{3} & Lazio & -14.0 & 1.1 & -1.4 & -2.4 & -5.2 & \multirow{2}{*}{-5.8} \\
\hline & Molise & -14.9 & -0.8 & -1.8 & -3.4 & -6.4 & \\
\hline \multirow{8}{*}{4} & Piedmont and Aosta Valley & -11.2 & 1.9 & -1.5 & -3.3 & -4.1 & \multirow{8}{*}{-4.6} \\
\hline & Lombardy & -11.7 & -0.1 & -2.0 & -1.4 & -4.6 & \\
\hline & Veneto & -13.9 & 1.3 & 0.0 & -3.4 & -5.1 & \\
\hline & Friuli Venezia Giulia & -9.0 & 0.2 & -0.2 & -4.5 & -4.0 & \\
\hline & Liguria & -10.1 & 2.2 & -1.4 & -3.2 & -3.5 & \\
\hline & Emilia Romagna & -11.0 & -0.4 & -1.7 & -2.5 & -4.7 & \\
\hline & Tuscany & -10.8 & -2.4 & -1.4 & -4.5 & -5.7 & \\
\hline & Marche & -11.7 & 0.0 & -3.1 & -4.6 & -5.3 & \\
\hline \multirow[t]{2}{*}{5} & Trentino Alto Adige & -9.0 & 0.7 & -2.1 & -2.4 & -3.6 & -3.6 \\
\hline & Italy & -13.6 & 0.0 & -1.3 & -3.4 & -5.6 & \\
\hline
\end{tabular}

Figure 5. Gender gap in Active Ageing Index (AAI) domain and overall scores in Italy, by region. Notes: Within clusters, regions are listed according to the ISTAT usually employed order, starting from North-Western regions descending to the South and lastly islands. E: Employment domain score. P: Participation in society domain score. I: Independent, healthy and secure living domain score. C: Capacity and enabling environment for active ageing domain score. AAl: overall AAI score.

Figure 5 shows the results concerning the gender gap (in terms of scores, negative values report the gap in favour of men). It could be considered that the lower the overall AAI score in a cluster, the higher the gender gap (that is, in any case, in favour of men).

The most evident gender differences are in the Employment domain. Exploring the regions, the highest gap is -19.3 in Campania (white cluster), while the lowest is in Trentino-Alto Adige (yellow cluster) with -9.0. In the Participation in society domain, seven Italian regions (Piedmont/Aosta Valley, Veneto, Friuli-Venezia Giulia, Liguria, Sardinia, Lazio, Trentino-Alto Adige and Campania) show a gender gap in favour of women, the highest being in Liguria and Sardinia (2.2). In this domain, the highest gender gap in favour of men is in Umbria $(-2.6)$, while there is no gender gap in the Marche Region.

In the third domain (Independent living), the gap also favours women in a few regions. This concerns Basilicata, Apulia (the highest gap is here with 1.3), Calabria and Sicily. The highest gap in favour of men is in Sardinia (-4.7). There is no gender gap in Veneto in this domain. In the fourth AAI domain (Capacity for active ageing), the gap is in favour of men, with the highest in Calabria (-5.6) and the lowest in Lombardy $(-1.4)$. In terms of overall score across regions, the highest gender gap is found in Campania (-7.5), while the lowest is in Trentino-Alto Adige (-3.6).

\section{Discussion}

This study's main hypothesis was that inequalities across Italian regions in terms of active ageing might occur beyond the classical tripartite (North, Centre, South) 
Italian geographical division. The hypothesis is confirmed even though a main tripartite gradient may still be identified. The application of the AAI at the regional level identified five regional clusters, grouped according to similarities and dissimilarities across AAI domains.

One northern region stands alone as a cluster unto itself (yellow cluster); another group includes the remaining northern regions and two central regions (blue cluster); the white cluster includes most of the southern regions, while the remaining two clusters (red and green) are geographically non-homogeneous groups (i.e. a mix of central and southern regions).

The results indicate that policy action may be needed, especially in the regions belonging to the white cluster, particularly in the Employment and Participation in society domains. This is not surprising, since the origins of the Italian geographical divide in terms of socio-economic and cultural factors, which have caused a problematic situation in the South, are well known (Putnam, 1993; Menniti et al., 2015; Federico et al., 2019). However, it is not the purpose of this study to go into greater detail about them. This work intends to show how appropriate regional active ageing policies may, to a certain extent, be successful in a southern context. The case of Basilicata (green cluster) can be used for illustrative purposes. Basilicata has been recognised at the national level as implementing 'good practices' in active ageing policies. Basilicata fully 'borders' the regions in the white cluster, yet these policies are mostly missing or non-effective in the latter regions. An example of effective active ageing policies in Basilicata is represented by the laboratori di comunità (community workshops), created to support volunteer activities from a community perspective, while also promoting integration and inclusion of citizens at risk of social exclusion (Barbabella et al., 2020b). In addition, worth noting is that while the blue (northern) cluster generally shows high scores, the northern region of Trentino-Alto Adige forms the cluster (yellow) on its own, being characterised by even higher scores. This could be both a matter of different cultural attitudes (in this region, $70 \%$ of the population primarily speaks German) and of particularly effective active ageing policies, recognised as best practices in this field. For instance, there are so-called Elki centres in Bolzano, which are meeting points for families with dependent children, where grandparents play a major role in contributing to social participation via games, story-telling, singing and crafts. In the AP of Trento, the 'Franco Demarchi Foundation' successfully develops educational and other activities for older people in many fields across the AP (Barbabella et al., 2020b).

While this first level of results (represented by the clusters) is useful for central government to understand priorities in allocating resources, the second level of results concerns, more analytically, the optimal potential allocation of resources by the regions within each cluster. As pointed out in this paper's Introduction, Italian regions have wide freedom of action in most active ageing dimensions. One prime example is that a lot could be done at the regional level to prepare the labour market for longer working lives, thus following commitment 5 (to enable labour markets to respond to the economic and social consequences of population ageing) of the Regional Implementation Strategy for the Madrid International Plan of Action on Ageing (UNECE, 2002) and goal 8 (promote sustained, inclusive and sustainable economic growth, full and productive employment and decent 
work for all) of the 2030 Agenda for Sustainable Development (United Nations, 2015). For instance, it is possible to encourage the adoption of companies' age management practices with specific policy actions, given that in Italy, these Human Resource Management practices are not widespread (Principi et al., 2015). For example, according to the results obtained in this study, within the white cluster, a more urgent need for policy actions in the employment dimension could be needed in Sicily and Apulia. This need could be linked to the general aim of trying to reduce the long-standing divide concerning economic development and labour market dynamism between Italian regions (Federico et al., 2019), which might be pursued by using part of the European funds (i.e. the Next Generation European Union fund package, to be translated into action by the implementation of the Italian Recovery and Resilience Plan) for tackling the socio-economic consequences of the COVID-19 pandemic.

However, this exercise could also affect regions included in other clusters. Still sticking to the example of the Employment dimension, priority policy intervention is needed in Sardinia in the green cluster and Piedmont/Aosta Valley in the blue one.

Still looking beyond the white cluster, the social participation domain in the regions of Molise (red cluster), Abruzzo (green cluster) and Liguria (blue cluster) seem to be particularly problematic. In Molise, no specific laws promote active ageing. One of the main criticalities has been identified in the lack of funds (Di Matteo, 2020). In Abruzzo, a law specifically promoting active ageing was enforced in 2016. Despite specific regional funds not being allocated to this purpose, the law could still count on European and national funds (Cela, 2020a); thus, the redistribution of resources to promote greater social participation by older people may benefit the region. The results obtained in Liguria in this domain are quite unexpected, since this region has for several years concentrated efforts and investment on active ageing policies, also in terms of economic resources, through a specific regional law enforced in 2009 (Cela, 2020b). Further research in this region should specifically address the indicators concurring with this active ageing domain, to identify specific fields in which policy action is needed.

When more or less obvious policy action needs are identified, the within-cluster investigation enables the development of main areas of intervention in any region. Even in the presence of a reasonably encouraging situation concerning national AAI scores, some regions may prefer to allocate resources specifically to one of the four AAI macro dimensions, where scores are not as high as those of other domains in relation to the national average.

This paper also highlights the considerable gender gap in active ageing outcomes in Italy in almost all of the active ageing domains, with few exceptions. In this respect, a recent investigation of the state of the art of active ageing policies in Italy found that the topic of equal opportunities for both genders in accessing active ageing is mostly neglected by existing national and regional laws and policies (Barbabella et al., 2020b). Therefore, urgent policy intervention is also required in this respect.

\section{Conclusions, limitations and further research}

This study contributes to the national and international debate on the societal usefulness of promoting active ageing (Walker, 2011), as also underlined by the 
international policy framework in this respect (UNECE, 2002; Foster and Walker, 2015). In particular, it increases the scant body of literature reporting national experiences on the application of the AAI at the regional level. Previous experiences of regional implementation are available for Poland and Spain. While the main limitation in the Polish study was the difference in a considerable number of indicators used from the original AAI-EU (Perek-Białas and Zwierzchowski, 2016), the small sample size in the Spanish study limited the possibility of comparing results between regions (Marsillas Rascado, 2019). These challenges make it difficult to compare the results of these previous studies with those obtained for Italy in the present study, which is affected to a limited extent by the latter, and a novel approach was introduced in the Italian case. It expands on AAI results and adds knowledge to provide more practical policy recommendations, addressing the need for more in-depth analyses (Marsillas Rascado, 2019). This proposed novel approach allows the central government level to deal more easily with resource allocation to regions, and the regions to recognise challenges in policy areas more clearly (i.e. where to allocate resources) for possible intervention. This study could inspire other countries that are planning on co-ordinating active ageing policy making across governmental levels.

To our knowledge, there is no evidence of bridging the AAI's results with concrete policies that were implemented as the result of the investigation and their effect on the active ageing indicators. There is an urgent research need in this respect. The present study was carried out within the project 'National Multilevel Co-managed Co-ordination of Active Ageing Policies in Italy', launched in 2019, and managed at the institutional level by the Department for Family Policies at the Presidency of the Council of Ministers (Barbabella et al., 2020a). The project relies on a large stakeholder network (representatives of Ministries, Departments at the Presidency of the Council of Ministers, Regions and APs, and also representatives from relevant non-profit organisations, unions, professional associations, academia and research bodies) and this study's results will be used for participative multilevel discussion in order to exploit them for policymaking purposes in an attempt to fill the identified gaps in Italy (Quattrociocchi et al., 2021). Further research should focus on the outcomes of this process in terms of policy making. The consultative and co-decisional approach (between policy makers and other relevant stakeholders) encourages bottom-up participation (Stenner et al., 2011; Falanga et al., 2021), also making it possible to consider older people's attitudes and preferences (Principi et al., 2018) and cultural differences, thus recognising multiple, differentiated ways of achieving wellbeing-related goals according to the context (Di Matteo et al., 2021).

This paper has several limitations that have to be considered. The main ones include the weaknesses identified in the AAI tool itself, as discussed above (Timonen, 2016; Amado et al., 2017; São José et al., 2017). While these cannot be fully removed, given that they are intrinsic to the underlying logic, one way to mitigate their impact could lie in using the participative approach discussed above. This would be particularly useful in the event of emergencies, such as the current pandemic, in which older people often risk being disproportionately affected but, at the same time, neglected by the adopted measures (UNECE, 2020). Another limitation concerns the availability of data. The exploitation of 
the AAI-IT as a longitudinal monitoring tool is partly jeopardised by the lack of (existing) data at the regional level for some of the requested variables, as highlighted in the Methods section. Whatever the reason for this lack of data, their use will be constrained for policy-making purposes until such time as the ISTAT makes these data fully accessible. A further limitation is that the index does not cover all aspects related to active ageing. Even though the multi-dimensionality of the concept was, to a considerable extent, acknowledged while building the index, active ageing must be observed from additional angles for an accurate analysis aimed at delivering policy insights. For example, it could be worth considering the role of leisure activities, which have been proven to be of considerable value for older people in contributing to good quality of life (Huijg et al., 2016; Principi et al., 2018). Another important aspect that is difficult to grasp through the AAI is the lifecourse perspective. It has been recognised that, for preventive purposes, it is highly important to promote healthy and active ageing well before old age is reached (Foster and Walker, 2015). Further research could adapt and apply the AAI to monitor different age groups and deliver messages targeting middle-aged and younger adults to address this challenge. Additionally, future investigations, especially at the regional level, should consider employing the index to address older people with a lower socio-economic status, and who traditionally face more barriers to accessing active ageing (Li and Ferraro, 2006; Thomas, 2011). Finally, future efforts should contemplate undertaking a more in-depth investigation of the 22 individual indicators composing the AAI. One of the main benefits of the AAI is that it delivers messages at different detail levels, and all of them are potentially useful. Once specific areas of intervention are identified at the domain level, it would be useful to destructure the domains to reach a more in-depth understanding of the underlying dynamics. This would allow a more targeted and, therefore, more effective formulation of policy recommendations.

Financial support. This work was supported the Department for Family Policies at the Presidency of the Council of Ministers; the Marche Region; and the Italian Ministry of Health (Ricerca Corrente funding to IRCCS INRCA).

\section{Notes}

1 See https://statswiki.unece.org/display/AAI/Active+Ageing+Index+Home.

2 Aosta Valley, Trentino-Alto Adige, Friuli-Venezia Giulia, Sicily and Sardinia. These regions have special forms and conditions of autonomy, pursuant to the respective special statutes adopted by constitutional law, taking into account relevant geographic and/or cultural specific features.

3 AAI-IT stands for 'Active Ageing Index built with Italian sources', as differentiated from AAI-EU, the original Active Ageing Index built at the European level in 2012. The differences between the AAI-IT and previous experiences of AAI built with Italian sources are explained in detail in Principi et al. (2020b). 4 See http://famiglia.governo.it/it/politiche-e-attivita/invecchiamento-attivo/progetto-di-coordinamentonazionale/.

\section{References}

Amado C, São José J and Santos S (2017) Measuring active ageing: a data envelopment analysis approach. European Journal of Operational Research 255, 207-223.

Barbabella F, Cela E, Di Matteo C, Socci M, Lamura G, Checcucci P and Principi A (2020a) New multilevel partnerships and policy perspectives on active ageing in Italy: a national Plan of Action. International Journal of Environmental Research and Public Health 17, 9585. 
Barbabella F, Checcucci P, Aversa ML, Scarpetti G, Fefè R, Socci M, Di Matteo C, Cela E, Damiano G, Villa M, Amari D, Montagnino SR, D'Agostino L, Iadevaia V, Ferrante A, Lamura G and Principi A (2020b) Le Politiche per l'Invecchiamento Attivo in Italia: Rapporto sullo Stato dell'Arte. Ancona and Rome, Italy: IRCCS INRCA and DIPOFAM. Available at http://famiglia.governo.it/media/2132/le-politiche-per-l-invecchiamento-attivo-in-italia.pdf.

Barrett G and McGoldrick C (2013) Narratives of (in)active ageing in poor deprived areas of Liverpool. International Journal of Sociology and Social Policy 33, 347-366.

Bauknecht J, Tiemann E and Velimsky JA (2016) Extending the Active Ageing Index to the Local Level in Germany: Pilot Study. Geneva and Brussels: United Nations Economic Commission for Europe and European Commission.

Bauknecht J, Hess M and Tiemann E (2017) Criteria-specific Analysis of the Active Ageing Index (AAI) at National Level in Germany. Geneva and Brussels: United Nations Economic Commission for Europe and European Commission.

Boudiny K (2013) 'Active ageing': from empty rhetoric to effective policy tool. Ageing \& Society 33, 10771098.

Bowling A (2005) Ageing Well: Quality of Life in Old Age. Maidenhead, UK: Open University Press.

Cabinet of Ministers (2016) Konceptuālais Ziņojums 'Aktīvās Novecošanās Stratēğija Ilgākam un Labākam Darba Mūžam Latvijā'. Riga: Cabinet of Ministers.

Cela E (2020a) Le Politiche per l'Invecchiamento Attivo nella Regione Abruzzo. Ancona and Rome, Italy: IRCCS INRCA and DIPOFAM. Available at http://famiglia.governo.it/media/2060/regione-abruzzo-politiche-invecchiamento-attivo.pdf.

Cela E (2020b) Le Politiche per l'Invecchiamento Attivo nella Regione Liguria. Ancona and Rome, Italy: IRCCS INRCA and DIPOFAM. Available at http://famiglia.governo.it/media/2100/regione-liguria-politiche-invecchiamento-attivo.pdf.

Cumming E and Henry W (1961) Growing Old. The Process of Disengagement. New York, NY: Basic Books.

Department of Health (2013) Positive Ageing Starts Now! The National Positive Ageing Strategy 2013-2017 in Ireland. Dublin: Department of Health.

Di Matteo C (2020) Le Politiche per l'Invecchiamento Attivo nella Regione Molise. Ancona and Rome, Italy: IRCCS INRCA and DIPOFAM. Available at http://famiglia.governo.it/media/1952/regione-molise-politiche-invecchiamento-attivo.pdf.

Di Matteo C, Lamura G and Principi A (2021) Active ageing: conceptual developments, international experiences and recent policy strategies in Italy. In Rojo-Perez F and Fernandez-Mayoralas G (eds), Handbook of Active Ageing and Quality of Life: From Concepts to Applications. Berlin: Springer International Publishing, pp. 593-607.

European Commission (1999) Towards a Europe for All Ages. Brussels: European Commission.

European Commission (2009) Dealing with the Impact of an Ageing Population in the EU. Brussels: European Commission.

European Council (2010) Council Conclusions on Active Ageing. Available at https://www.consilium.europa.eu/uedocs/cms_Data/docs/pressdata/en/lsa/114968.pdf.

Falanga R, Cebulla A, Principi A and Socci M (2021) The participation of senior citizens in policymaking: patterning initiatives in Europe. International Journal of Environmental Research and Public Health 18, 34.

Federico G, Nuvolari A and Vasta M (2019) The origins of the Italian regional divide: evidence from real wages, 1861-1913. Journal of Economic History 79, 63-98.

Felice E (2018) The socio-institutional divide: explaining Italy's long-term regional differences. Journal of Interdisciplinary History 49, 43-70.

Ferrera M (1996) The 'southern' model of welfare in social Europe. Journal of European Social Policy 6, 17-37.

Foster L and Walker A (2015) Active and successful aging: a European policy perspective. The Gerontologist 55, 83-90.

Foster L and Walker A (2021) Active ageing across the life course: towards a comprehensive approach to prevention. BioMed Research International 2021, 6650414.

Ghisalberti C (1986) Accentramento e decentramento in Italia. In De Rosa L and Di Nolfo E (eds), Regionalismo e Centralizzazione nella Storia di Italia e Stati Uniti. Florence, Italy: Olschki. 
Groppi T and Scattone N (2006) Italy: the subsidiarity principle. International Journal of Constitutional Law 4, 131-137.

Havighurst RJ (1961) Successful aging. The Gerontologist 1, 8-13.

Huijg J, van Delden A, van der Ouderaa F, Westendorp R, Slaets J and Lindenberg J (2016) Being active, engaged, and healthy: older persons' plans and wishes to age successfully. Journals of Gerontology: Psychological Sciences and Social Sciences 72B, 228-236.

IMAD (2018) Active Ageing Strategy. Ljubljana: Institute of Macroeconomic Analysis and Development of the Republic of Slovenia and Ministry of Labour, Family, Social Affairs and Equal Opportunities.

ISTAT (2019a) Annuario Statistico Italiano 2019. Rome: Istituto Nazionale di Statistica.

ISTAT (2019b) La Salute nelle Regioni Italiane. Bilancio di un Decennio (2005-2015). Rome: Istituto Nazionale di Statistica.

ISTAT (2020a) Conti Economici Territoriali Anni 2016-2018. Rome: Istituto Nazionale di Statistica.

ISTAT (2020b) Indicatori territoriali per le politiche di sviluppo. Indicatori per Tema. Available at https:// www.istat.it/it/archivio/16777.

Karpinska K and Dykstra P (2015) The Active Ageing Index and Its Extension to the Regional Level. Brussels: European Commission, Directorate-General for Employment, Social Affairs and Inclusion.

Lamura G, Principi A and Di Rosa M (2019) 2018 Active Ageing Index Analytical Report. Geneva and Brussels: United Nations Economic Commission for Europe and European Commission.

Leonardi R, Nanetti RY and Putnam RD (1981) Devolution as a political process: the case of Italy. Publius 11, 95-117.

Li Y and Ferraro KF (2006) Volunteering in middle and later life: is health a benefit, barrier or both? Social Forces 85, 497-519.

López-López R and Sánchez M (2020) The institutional active aging paradigm in Europe (2002-2015). The Gerontologist 60, 406-415.

Marche Region (2019) Regional Law 28 January 2019. n. 1: Promotion of Active Ageing. Available at https:// www.consiglio.marche.it/banche_dati_e_documentazione/leggi/dettaglio.php?arc=vig\&idl=2078.

Marsillas Rascado S (2019) Active Ageing Index at Subnational Level in Spain. Geneva and Brussels: United Nations Economic Commission for Europe and European Commission.

Menniti A, Demurtas P, Arima S and De Rose A (2015) Housework and childcare in Italy: a persistent case of gender inequality. Genus 71, 79-108.

MPSV (2014) National Action Plan for Positive Ageing for the Period 2013-2017. Prague: Ministry of Labour and Social Affairs.

National Commission for Active Ageing (2014) National Strategic Policy for Active Ageing: Malta 20142020. Valletta: Parliamentary Secretariat for Rights of Persons with Disability and Active Ageing.

Naydenova Z (2019) National Strategy for Active Ageing in Bulgaria (2019-2030). Sofia: Ministry of Labour and Social Policy. Available at https:/unece.org/fileadmin/DAM/pau/age/WG.12/Presentations/ 2_National-Strategy-Active-Ageing-Bulgaria.pdf.

Palmore EB (1995) Successful aging. In Maddox GL (ed.), Encyclopedia of Aging: A Comprehensive Resource in Gerontology and Geriatrics, 2nd Edn. New York, NY: Springer, pp. 914-915.

Perek-Białas J and Zwierzchowski J (2016) Wskaźnik Aktywnego Starzenia w Ujęciu Regionalnym - 2015. Warsaw: Departamentu Polityki Senioralnej Ministerstwo Rodziny, Pracy i Polityki Społecznej. Available at https://das.mpips.gov.pl/source/AAI\%20w\%20ujeciu\%20regionalnym\%202015.pdf.

Perek-Białas J, Zwierzchowski J, Antczak R and Panek T (2017) Criteria Specific Analysis of the Active Ageing Index at the National Level in Poland: 2007-2015. Geneva and Brussels: United Nations Economic Commission for Europe and European Commission.

Petretto DR, Pili R, Gaviano L, Matos López C and Zuddas C (2016) Envejecimiento activo y de éxito o saludable: una breve historia de modelos. Revista Española de Geriatría y Gerontología 51, 229-241.

Pfaller L and Schweda M (2019) Excluded from the good life? An ethical approach to conceptions of active ageing. Social Inclusion 7, 44-53.

Principi A, Jensen PH and Lamura G (2014) Active Ageing: Voluntary Work by Older People in Europe. Bristol, UK: Policy Press.

Principi A, Fabbietti P and Lamura G (2015) Perceived qualities of older workers and age management in companies: does the age of HR managers matter? Personnel Review 44, 801-820. 
Principi A, Galenkamp H, Papa R, Socci M, Suanet B, Schmidt A, Schulmann K, Golinowska S, Sowa A, Moreira A and Deeg D (2016a) Do predictors of volunteering in older age differ by health status? European Journal of Ageing 13, 91-102.

Principi A, Schippers J, Naegele G, Di Rosa M and Lamura G (2016b) Understanding the link between older volunteers' resources and motivation to volunteer. Educational Gerontology 42, 144-158.

Principi A, Santini S, Socci M, Smeaton D, Cahill KE, Vegeris S and Barnes E (2018) Retirement plans and active ageing: perspectives in three countries. Ageing \& Society 38, 56-82.

Principi A, Tibaldi M, Quattrociocchi L and Checcucci P (2019) Criteria-specific Analysis of the Active Ageing Index (AAI) in Italy. Geneva and Brussels: United Nations Economic Commission for Europe and European Commission.

Principi A, Smeaton D, Cahill K, Santini S, Barnes H and Socci M (2020a) What happens to retirement plans, and does this affect retirement satisfaction? International Journal of Aging and Human Development 90, 152-175.

Principi A, Varlamova M, Lamura G, Socci M and Di Rosa M (2020b) Building the Active Ageing Index with Italian Sources - Technical Report. Ancona and Rome, Italy: IRCCS INRCA and DIPOFAM. Available at http://famiglia.governo.it/media/2191/aai-italy-technical-report.pdf.

Putnam RD (1993) Making Democracy Work: Civic Traditions in Modern Italy. Princeton, NJ: Princeton University Press.

Quattrociocchi L, Tibaldi M, Marsili M, Fenga L and Caputi M (2021) Active ageing and living condition of older persons across Italian regions. Journal of Population Ageing 14, 91-136.

Rowe J and Kahn R (1987) Human ageing: usual and successful. Science 237, 143-149.

Rowe J and Kahn R (1997) Successful aging. The Gerontologist 37, 433-440.

São José JM, Timonen V, Amado CA and Santos SP (2017) A critique of the Active Ageing Index. Journal of Aging Studies 40, 49-56.

Stenner A, McFarquhar T and Bowling A (2011) Older people and 'active ageing': subjective aspects of ageing actively. Journal of Health Psychology 16, 467-477.

Thomas PA (2011) Gender, social engagement, and limitations in late life. Social Science \& Medicine 73, 1428-1435.

Timonen V (2016) Beyond Successful and Active Ageing. A Theory of Model Ageing. Bristol, UK: Policy Press.

United Nations (2015) Transforming Our World: The 2030 Agenda for Sustainable Development. New York, NY: United Nations.

United Nations Economic Commission for Europe (UNECE) (2002) Regional Implementation Strategy for the Madrid International Plan of Action on Ageing 2002 (ECE/AC.23/2002/2/Rev.6). Berlin: ECOSOC and UNECE.

United Nations Economic Commission for Europe (UNECE) (2020) Older Persons in Emergency Situations (UNECE Policy Brief on Ageing No. 25). Geneva: UNECE.

United Nations Economic Commission for Europe (UNECE) and European Commission (2018) Active Ageing Index (AAI) in Non-EU Countries and at Subnational Level: Guidelines. Geneva and Brussels: UNECE and European Commission.

Villar F (2012) Successful ageing and development: the contribution of generativity in older age. Ageing \& Society 32, 1087-1105.

Walker A (2011) The Future of Ageing Research in Europe: A Road Map. Sheffield, UK: University of Sheffield.

World Health Organization (WHO) (1990) Healthy Ageing. Geneva: WHO.

World Health Organization (WHO) (2002) Active Ageing: A Policy Framework. Geneva: WHO.

Zaidi A and Stanton D (2015) Active Ageing Index 2014: Analytical Report. Geneva and Brussels: United Nations Economic Commission for Europe and European Commission.

Zaidi A, Gasior K, Hofmarcher MM, Lelkes O, Marin B, Rodrigues R, Schmidt A, Vanhuysse P and Zolyomi E (2013) Active Ageing Index 2012. Concept, Methodology and Final Results. Vienna: European Centre for Social Welfare Policy and Research.

Cite this article: Principi A, Di Rosa M, Domínguez-Rodríguez A, Varlamova M, Barbabella F, Lamura G, Socci M (2021). The Active Ageing Index and policy making in Italy. Ageing \& Society 1-26. https:// doi.org/10.1017/S0144686X21001835 